\title{
Interaction of human endothelial cells with elevated glucose concentrations and native and glycosylated low density lipoproteins
}

\author{
M. Lorenzi, E. Cagliero, B. Markey, T. Henriksen, J.L. Witztum, and T. Sampietro \\ Department of Medicine, Division of Metabolic Diseases, University of California, San Diego, La Jolla, California, USA
}

\begin{abstract}
Summary. We have investigated whether and how the elevated glucose concentrations characteristic of diabetes may alter the interaction of endothelial cells with low-density lipoproteins (LDL). Protracted exposure of cultured human endothelial cells to $20 \mathrm{mmol} / 1$ glucose failed to affect either the relationship between the degree of confluency of the monolayer and the extent of LDL degradation or the dose-responses for LDL uptake and degradation. In contrast, non-enzymatic glycosylation of LDL by pre-incubation of LDL with glucose markedly inhibited their uptake and degradation by endothelial cells. Thus, at protein concentration of $5 \mu \mathrm{g} / \mathrm{ml}$, the amount of glycosylated ${ }^{125} \mathrm{I}$-LDL associated with cells was decreased fourfold compared with native ${ }^{125}$ I-LDL (47 \pm 3 versus $194 \pm$
\end{abstract}

$10 \mathrm{ng} \cdot \mathrm{mg}$ cell protein ${ }^{-1} \cdot 24 \mathrm{~h}^{-1}$, mean $\pm \mathrm{SEM}$ ), and degradation was decreased twenty-fold $(135 \pm 4$ versus $2873 \pm$ $115 \mathrm{ng} \cdot \mathrm{mg}$ cell protein ${ }^{-1} \cdot 24 \mathrm{~h}^{-1}$ ). The degree of inhibition was proportional to the extent of glycosylation. At all concentrations studied, methylated LDL behaved similarly to glycosylated LDL. The decreased recognition of glycosylated LDL by the endothelial lining of small and large blood vessels may have an impact on tissue physiology and on the overall fate of the glycosylated molecules.

Key words: Human endothelial cells, glucose, low density lipoproteins, contact inhibition, glycosylation, methylation.
Since no unique pathogenic element has yet been implicated as the link between diabetes and the accelerated atherosclerosis affecting diabetic patients of all age groups $[1,2]$, it seems reasonable to investigate whether and how diabetes may alter the interactions between participants in the atherogenic process: low density lipoproteins (LDL), the source of most of the cholesterol present in vascular lesions [3] and cellular elements of the vessel wall. Previous investigations addressing this question have focussed on the interactions of LDL with fibroblasts or macrophages [4-9]. Yet it is the endothelium that is in contact with the blood and first participates in LDL metabolism. Endothelial cells take up and degrade LDL through both receptor-dependent and independent mechanisms [10-12]. We sought to determine whether protracted elevation of ambient glucose may alter these interactions. We have thus studied LDL receptor function in human endothelial cells cultured in elevated glucose concentrations and, conversely, the consequences of increased glycosylation of LDL, known to occur in diabetic patients $[7,13]$, on its recognition and handling by endothelial cells.

\section{Materials and methods}

\section{Cell cultures}

Primary endothelial cell cultures from human umbilical veins were established according to the method of Jaffe et al. [14] with slight modifications. Briefly, umbilical cords were obtained from normal or Caesarean-section full-term deliveries and stored at $4^{\circ} \mathrm{C}$ in sterile phosphate-buffered saline (PBS, $0.15 \mathrm{~mol} / 1, \mathrm{pH} 7.4$ ), with penicillin $(500 \mathrm{units} / \mathrm{ml})$ and streptomycin $(500 \mu \mathrm{g} / \mathrm{ml})$ until use $1-3 \mathrm{~h}$ later. Under sterile conditions, the cord ends were cleanly cut and the vein lumen cannulated at each end. After $50-100 \mathrm{ml}$ of PBS had been flushed through to remove any blood, $15-20 \mathrm{ml}$ of $0.2 \%$ collagenase (Sigma Type I, approximately $200 \mathrm{U}$ collagenase/ml dry weight; Sigma Chemicals, St. Louis, Missouri, USA) solution was instilled, distending the vein lumen, and the ends were clamped. The cord was then placed in a sterile $37^{\circ} \mathrm{C}$ water bath for 15-20 min. After incubation, two $50-\mathrm{ml}$ syringes and an additional $30 \mathrm{ml}$ of PBS were used to flush the luminal content back and forth five to six times which was then collected in a centrifuge tube containing $10 \mathrm{ml}$ of culture medium (Medium 199, Gibco Laboratories, Grand Island, New York, USA), supplemented with glutamine $(2 \mathrm{mmol} / \mathrm{l})$, Hepes buffer $(17.5$ $\mathrm{mmol} / \mathrm{l}$ ), and $20 \%$ fetal calf serum, the latter added in order to inactivate the collagenase. The cellular suspension was then centrifuged at $5^{\circ} \mathrm{C}$, the supernatant discarded and the cell pellet gently resuspended in $2 \mathrm{ml}$ of medium per cord. We generally processed two to three 


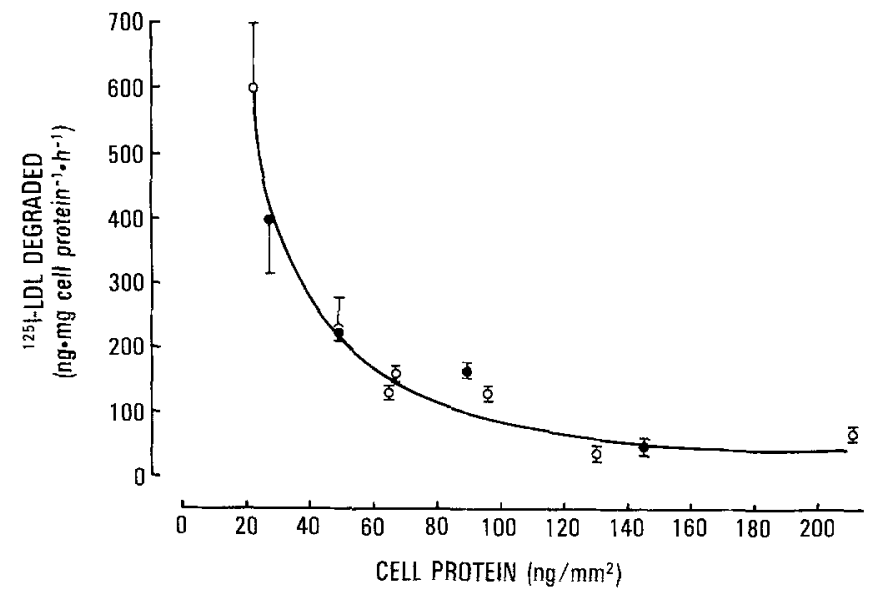

Fig. 1. Inverse relationship between degree of confluence of the endothelial cell monolayer (reflected in the cell protein per surface area of the culture dish) and degradation of ${ }^{125} \mathrm{I}-\mathrm{LDL}(5 \mu \mathrm{g} / \mathrm{ml})$. The relation was unaffected by exposure of endothelial cells for 5-10 days to $20 \mathrm{mmol} / 1$ glucose. Each point represents the mean $\pm S E M$ of three or four determinations. $O=5 \mathrm{mmol} / 1$ glucose; $=20 \mathrm{mmol} / 1$ glucose

cords at the same time and pooled the harvested cells. Cells were seeded at a density of $1 \times 10^{5}$ in $17 \mathrm{~mm}$ wells (Falcon, Oxnard, California, USA) and $2 \times 10^{5}$ in $35 \mathrm{~mm}$ dishes and placed in the incubator (Forma Scientific, model 3157, Marietta, Ohio, USA). The following day, the medium was removed, the cells were washed once with PBS and fresh medium containing $14 \%$ heat-inactivated pooled human serum was added. In our experience, the sequence of fetal calf serum at plating followed by human serum after $24 \mathrm{~h}$ has resulted in the best growth performance for human umbilical vein endothelium.

Volumes of incubation were $2 \mathrm{ml}$ for $35 \mathrm{~mm}$ dishes, and $1 \mathrm{ml}$ for $17 \mathrm{~mm}$ wells. All cultures were incubated at $37^{\circ} \mathrm{C}$ in a humidified $5 \%$ $\mathrm{CO}_{2}: 95 \%$ air atmosphere and, in order to preserve sterility, all media were filtered and supplemented with penicillin $(50$ units $/ \mathrm{ml})$ streptomycin $(50 \mu \mathrm{g} / \mathrm{ml})$ and fungizone $(0.25 \mu \mathrm{g} / \mathrm{ml})$ purchased from Irvine Scientific, Irvine, California, USA. Media were changed twice weekly. When monolayers were $60 \%-70 \%$ confluent, the medium in experimental dishes was supplemented with D-glucose (Sigma) in order to achieve glucose concentrations of $20 \mathrm{mmol} / 1$ (versus $5 \mathrm{mmol} / 1$ in control dishes). This concentration was chosen to match glucose levels in uncontrolled but non-ketotic diabetic patients. The accuracy of addition and stability of the glucose concentration in incubation media was verified by frequent determinations (Beckman glucose analyzer, Beckman Instruments, Fullerton, California, USA). Exposure to high glucose levels was continued for $8-10$ days. Insulin levels in the pooled human sera were $8-12 \mathrm{mU} / 1$ (Autopak-12 insulin radioimmunoassay by Micromedic Systems, Horsham, Pennsylvania, USA). Owing to serum dilution in the culture medium, cells were exposed to subphysiological levels of insulin. The experimental culture conditions thus matched the glucose: insulin ratio characteristic of insulin-deficient diabetes. The presence of factor VIII-related antigen on endothelial cells was tested with an immunoperoxidase method (Histoset Kit, Immunolok, Carpinteria, California, USA).

\section{LDL uptake and degradation experiments}

Human LDL was prepared and radioiodinated as described previously [7, 15] using carrier-free $\mathrm{Na}^{125} \mathrm{I}$ (Amersham/Searle, Arlington Heights, Illinois, USA). Glycosylation was achieved by incubating the iodinated LDL for 7 days in $80 \mathrm{mmol} / 1$ glucose; in these experiments, $15-18 \%$ of the lysines were glycosylated, as judged by the trinitrobenzenesulphonic acid assay [16]. To achieve higher degrees of glycosylation some LDL preparations were incubated in glucose $(80 \mathrm{mmol} / \mathrm{l})$ in the presence of fresh cyanoborohydride (J.T. Baker Chemicals, Phillipsburg, New Jersy, USA) dissolved in PBS to a final concentra- tion of $12.5 \mathrm{mg} / \mathrm{ml}$. Under these conditions, $40 \%-60 \%$ of the lysine residues were glycosylated.

Initially, control LDL was subjected to all the steps employed in glycosylation except that glucose was omitted from the incubation mixture. However, upon observing that its behaviour was indistinguishable from that of freshly prepared LDL, we used the latter in subsequent studies. Reductive methylation of LDL was performed by the method of Weisgraber et al. [17]. With this procedure $>80 \%$ of LDL lysine residues are blocked by methyl groups as measured in the trinitrobenzenesulphonic acid assay.

Twenty-four hours before exposure to test LDL, cultures were switched to medium containing 5\% lipoprotein-deficient human serum prepared as described previously [15]. Uptake and degradation studies were initiated by providing the cell cultures with fresh medium also containing 5\% lipoprotein-deficient serum and the appropriate concentrations of ${ }^{125} \mathrm{I}-\mathrm{LDL}$ proteins: 5 or $20 \mu \mathrm{g} / \mathrm{ml}$ in order to test high-affinity receptor functions [3] and $400 \mu \mathrm{g} / \mathrm{ml}$ to test overall endothelial handling of LDL concentrations to which these cells are physiologically exposed in vivo [18]. The different glucose concentrations were maintained in all experimental media. Plates without cells were incubated under the same conditions to control for spontaneous breakdown of the labelled LDL.

After incubation for 14-24h, LDL degradation products were measured in the medium by adding serum albumin $(1 \mathrm{mg} / \mathrm{ml})$ and trichloroacetic acid (10\% final concentration). The trichlorocetic acid soluble material was treated with silver nitrate $(10 \mathrm{mg} / \mathrm{ml})$ in order to precipitate free iodine and after centrifugation, the supernatant was drawn through a $0.22 \mathrm{um}$ pore-diameter filter and ${ }^{125} \mathrm{I}$ was counted in a Searle automatic gamma system (model 1197, Des Plaines, Illinois, USA). The cell monolayers were washed five times with ice-cold PBS, scraped from the dishes, and sonicated. Aliquots were taken for counting to yield cell-associated radioactivity and for protein determination by the method of Lowry et al. [19]. Degradation products are expressed in $\mathrm{ng} \cdot \mathrm{mg}$ cell protein $\mathrm{n}^{-1} \cdot \mathbf{h}^{-1}$ or per total period of incubation; cell-associated LDL in $\mathrm{ng} / \mathrm{mg}$ cell protein. In the experiments relating LDL degradation to degree of confluency of the monolayer, in order to establish comparison between endothelial cells cultured in different size plates, the total amount of protein per dish was related to the surface area ( 961 for $35 \mathrm{~mm}, 226$ for $17 \mathrm{~mm}$ ) and is thus expressed in $\mathrm{ng} / \mathrm{mm}^{2}$.

Data are expressed as mean $\pm S E M$ of triplicate-quadruplicate determinations in two to three identical experiments. Statistical analysis was performed using the two-tailed Student's t-test.

\section{Results}

\section{Effects of elevated glucose on cell viability, morphology and total protein}

Human endothelial cells cultured for up to 12 days in $20 \mathrm{mmol} / 1$ glucose and control cells consistently excluded Trypan blue. No morphological differences could be detected in endothelial cell monolayers cultured in normal or high glucose concentrations by phase-contrast microscopy.

The presence of $20 \mathrm{mmol} / 1$ glucose in the culture medium for 4-12 days did not modify the total cell protein content per dish. The amount of total protein of cells cultured in $5 \mathrm{mmol} / 1$ glucose was $150 \pm 10 \mathrm{ng} / \mathrm{mm}^{2}$ at confluency versus $149 \pm 14 \mathrm{ng} / \mathrm{mm}^{2}$ for monolayers cultured in $20 \mathrm{mmol} / 1$ glucose. Uniform reactivity for factor VIII antigen was observed in endothelial cells cultured in normal or high glucose concentrations. 


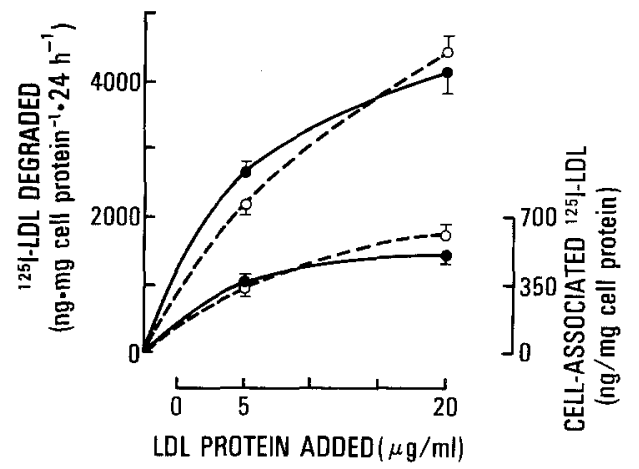

Fig. 2. Dose-response curves for ${ }^{125} \mathrm{I}-\mathrm{LDL}$ uptake (expressed as cellassociated radioactivity) and degradation by endothelial cells maintained in normal $(5 \mathrm{mmol} / \mathrm{l})$ or elevated $(20 \mathrm{mmol} / \mathrm{l})$ glucose concentrations for 8-10 days. Each point represents the mean \pm SEM of six to nine determinations obtained in two or three identical experiments. $O=5 \mathrm{mmol} / 1$ glucose $;=20 \mathrm{mmol} / 1$ glucose

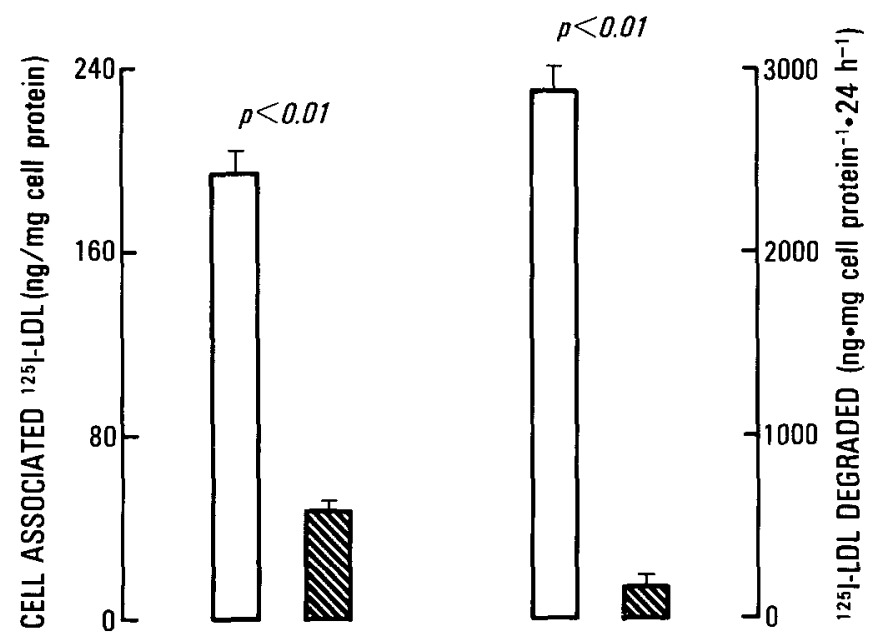

LDL PROTEIN ADDED $5 \mu \mathrm{g} / \mathrm{ml}$

Fig.3. Effect of glycosylation of $16 \%$ of LDL lysine residues on uptake and degradation by endothelial cell high affinity LDL receptors. Each bar represents the mean \pm SEM of eight determinations obtained in two identical experiments. $\square=$ control LDL; $=$ glycosylated LDL

\section{Effects of elevated glucose on uptake and degradation of native $L D L$}

The inverse relationship between degree of confluency and rate of LDL degradation described in bovine aortic endothelium [11] was also demonstrated in human endothelial cells (Fig.1): LDL degradation rate was $603 \pm 95 \mathrm{ng} \cdot \mathrm{mg}$ cell protein ${ }^{-1} \cdot \mathrm{h}^{-1}$ in dividing cultures and fell to $36-68 \mathrm{ng} \cdot \mathrm{mg}$ cell protein ${ }^{-1} \cdot \mathrm{h}^{-1}$ in confluent cultures (cell protein content $130-211 \mathrm{ng} / \mathrm{mm}^{2}$ ). Exposure to $20 \mathrm{mmol} / 1$ glucose for various intervals from the time of plating did not alter the relationship between state of confluency and rate of LDL degradation by human endothelial cells (Fig. 1).

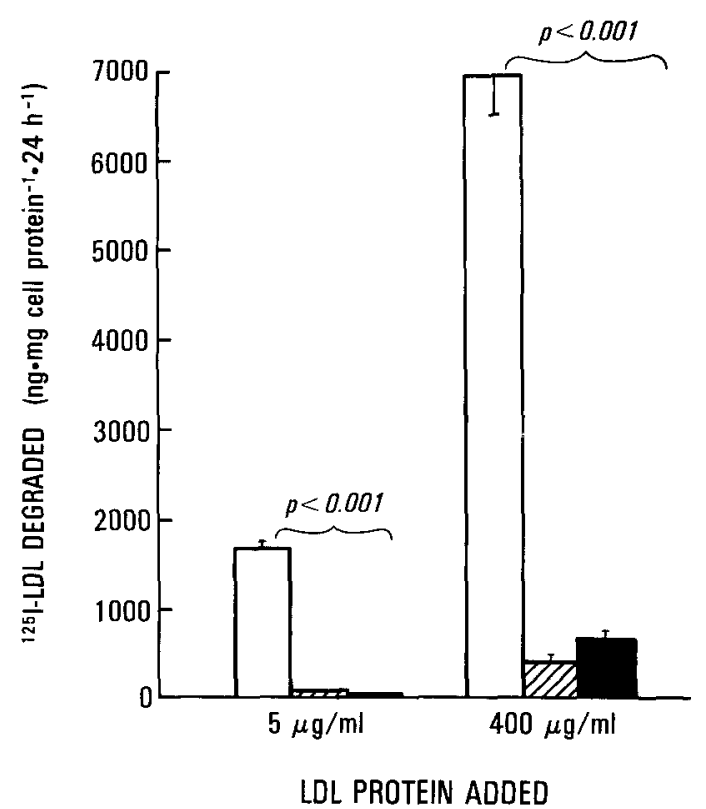

Fig.4. Effect of extensive glycosylation or methylation of LDL on degradation by endothelial cells. The indicated concentrations of LDL were employed to test high-affinity receptor $(5 \mu \mathrm{g} / \mathrm{ml})$ and overall handling of physiological concentrations of LDL $(400 \mu \mathrm{g} / \mathrm{ml})$. Each bar represents the mean \pm SEM of eight to ten determinations in two or three identical experiments. $\square=$ control LDL; $\bigotimes=$ glycosylated LDL; $=$ methylated LDL

The dose-response curve for cell-association and degradation of LDL by endothelial cells was similarly unaltered by $8-10$ days exposure to an elevated glucose concentration (Fig. 2).

\section{Glycosylated and methylated LDL}

${ }^{125}$ I-glycosylated LDL was prepared by incubation of glucose and LDL and 16\% of the lysine residues were glycosylated (Fig. 3). When endothelial cells were incubated with this glycosylated LDL, cell-associated radioactivity was $47 \pm 3 \mathrm{ng} / \mathrm{mg}$ cell protein, in contrast with $194 \pm 10 \mathrm{ng} / \mathrm{mg}$ cell protein for native LDL and degradation was markedly reduced: $135 \pm 4$ versus $2873 \pm$ $115 \mathrm{ng} \cdot \mathrm{mg}$ cell protein ${ }^{-1} \cdot 24 \mathrm{~h}^{-1}$ for native LDL.

When up to $40 \%$ of lysines were glycosylated as result of incubation of LDL and glucose in the presence of cyanoborohydride, the difference in degradation was even more marked: while native $\operatorname{LDL}(5 \mu \mathrm{g} / \mathrm{ml})$ yielded $1648 \pm 140 \mathrm{ng} \cdot \mathrm{mg}$ cell protein ${ }^{-1} \cdot 24 \mathrm{~h}^{-1}$, degradation products from glycosylated LDL were $27 \pm 10 \mathrm{ng} \cdot \mathrm{mg}$ cell protein ${ }^{-1} \cdot 24 \mathrm{~h}^{-1}$. Values were similarly reduced for methylated LDL $\left(15 \pm 1 \mathrm{ng} \cdot \mathrm{mg}\right.$ cell protein ${ }^{-1} \cdot 24 \mathrm{~h}^{-1}$; Fig. 4). When expressed in ng/dish, the values for degradation products of glycosylated and methylated LDL were not different from spontaneous degradation of the modified LDL in dishes without cells. Exposure of human cells to a high concentration of LDL $(400 \mu \mathrm{g} / \mathrm{ml})$, mimicking levels physiologically bathing vascular endothelium and super-saturating high-affinity LDL re- 
ceptors, resulted in increased degradation products for all types of LDL: $6961 \pm 430$ for native, $401 \pm 36$ for glycosylated and $728 \pm 22 \mathrm{ng} \cdot \mathrm{mg}$ cell protein ${ }^{-1} \cdot 24 \mathrm{~h}^{-1}$ for methylated LDL. The values for lysine-modified LDL, albeit much smaller than for native LDL $(p<0.001)$, are indicative of at least some cell-mediated degradation, presumably occurring through non-receptor mechanisms, since the absolute amount of LDL degradation products per dish ranged from 12 to $36 \mathrm{ng} / 24 \mathrm{~h}$, while control dishes without cells only yielded values between 2 and $6 \mathrm{ng} / 24 \mathrm{~h}$.

\section{Discussion}

Among the constituents of the vessel wall, endothelial cells might be the first to be affected by the abnormal metabolic milieu of diabetes as they face it directly. We have investigated whether prolonged exposure of vascular endothelial cells to high glucose levels alters the function of specific membrane recognition sites, particularly high-affinity receptors for low-density lipoproteins $[10,11]$. In our experiments, human endothelial cells cultured in high glucose concentrations maintained an unaltered dose-response for LDL uptake and degradation and the same inverse relationship between the state of confluency and LDL degradation exhibited by control cells. This was observed using glucose concentrations and duration of exposure reported to result in appreciable non-enzymatic glycosylation of various tissues [20, 21] and proteins [22]. Thus, possible biochemical changes induced by protracted elevation of ambient glucose do not appear to affect the function of LDL receptors on endothelial cells nor to modify the characteristics of contact inhibition that mediate the decreased internalization of LDL in confluent monolayers of endothelial cells [11]. However, when exposure to high glucose had modified the LDL ligand, significant impairment of interaction with the receptor was observed, resulting in reduced cellular uptake and degradation of LDL. The fact that the behaviour of methylated LDL was similar to that of glycosylated LDL at all LDL concentrations studied indicates that reactive $\varepsilon$ amino groups of lysine, crucial for the recognition of LDL by fibroblast receptors $[17,18]$, are as important for physiological interaction with endothelial cells receptors. As in fibroblasts [17], the LDL recognition sites of endothelial cells appear sensitive to modification of a small fraction of the lysine groups of the ligand in that a substantial reduction in internalization and degradation was observed when only $16 \%$ of the LDL lysines were glycosylated.

In assessing the possible clinical relevance of these observations in vitro, the first point of interest relates to the substantial amount of LDL internalized and degraded by the primary cultures of human endothelial cells, even in the post-confluent state. This is in contrast with the cessation of LDL internalization observed in established lines of bovine endothelial cells upon development of contact inhibition [11] and cannot be attributed to the lack of fibroblast growth factor in the culture medium, since Coetzee et al. have reported similar results for human endothelial cells cultured in the presence of fibroblast growth factor [12]. Because our cultures were exposed to lipoprotein-deficient serum prior to testing, and may thus have increased their number of LDL receptors [3], our results may overestimate the magnitude of LDL receptor activity expressed by endothelial cells in vivo. However, Carew et al. [23] have shown recently in rabbits in vivo that endothelial cells account for $40 \%$ of total aortic degradation of LDL and that on the basis of tissue protein content, endothelium is about 40 times more active in LDL degradation than the rest of the aorta. Moreover, of this LDL degradation, $48 \%$ was receptor-dependent.

If then LDL uptake and degradation by the high-affinity receptor is physiologically important for endothelial cells, interference with its function by modification of the ligand may have untoward effects. Albeit to lesser degrees than we have tested in our model, increased glycosylation of LDL has been demonstrated in diabetic patients [7, 13] and LDL isolated from poorly controlled diabetic subjects have been shown in at least one study [8] to be internalized and degraded by fibroblasts less than LDL obtained after optimization of metabolic control. In addition, glycosylation of LDL in only $20 \mathrm{mmol} / 1$ glucose, resulting in $3 \%-5 \%$ of lysine residues derivatized, a level seen in some diabetic subjects, has been found to reduce significantly the plasma clearance of LDL in the guinea pig [24].

A process may be envisaged whereby diminished uptake of initially mildly glycosylated LDL by endothelial cells throughout the vascular system may build a pool of increasingly glycosylated molecules whose turnover in the circulation becomes prolonged, thus contributing to the LDL elevation observed in diabetic patients [25] and eventually even constituting an antigenic challenge for the immune system [26]. Whether the disturbed relationship with the modified LDL may also impinge on endothelial cell physiology is worthy of further investigation.

Acknowledgments. We are indebted to S. Toledo for excellent technical assistance and Dr. D. Steinberg for helpful discussion. Dr. T. Sampietro was on leave of absence from the C.N.R. Institute of Clinical Physiology, Pisa, Italy. This work was supported in part by a grant from the American Diabetes Association to Dr. Lorenzi.

\section{References}

1. Christy JH, Clements SD (1982) The heart and endoctine diseases. In: Hurst JW (ed) The heart. McGraw-Hill, New York, pp 1547-1567

2. Crall FVJr, Roberts WC (1978) The extramural and intramural coronary arteries in juvenile diabetes mellitus. Am J Med 64: 221-230 
3. Goldstein JL, Brown MS (1977) The low-density lipoprotein pathway and its relation to atherosclerosis. Ann Rev Biochem 46: $897-930$

4. Chait A, Bierman EL, Albers JJ (1979) Low density lipoprotein receptor activity in fibroblasts cultured from diabetic donors. Diabetes 28: 914-918

5. Chait A, Bierman EL, Albers JJ (1978) Regulatory role of insulin in the degradation of low density lipoprotein by cultured human skin fibroblasts. Biochim Biophys Acta 529: 292-299

6. Gonen B, Baenziger J, Schonfeld G, Jacobson D, Farrar P (1981) Non-enzymatic glycosylation of low density lipoproteins in vitro. Diabetes 30: 875-878

7. Witztum JL, Mahoney EM, Branks MJ, Fisher M, Elam R, Steinberg D (1982) Non-enzymatic glucosylation of low-density lipoprotein alters its biologic activity. Diabetes 31: 283-291

8. Lopes-Virella MF, Sherer GK, Lees AM, Wohltmann H, May field R, Sagel J, LeRoy EC, Colwel JA (1982) Surface binding, internalization and degradation by cultured human fibroblasts of low density lipoproteins isolated from Type I (insulin-dependent) diabetic patients: changes with metabolic control. Diabetologia 22: $430-436$

9. Kraemer FB, Chen Y-DI, Cheung RMC, Reaven GM (1982) Are the binding and degradation of low density lipoprotein altered in Type 2 (non-insulin-dependent) diabetes mellitus? Diabetologia 23: $28-33$

10. Reckless JPD, Weinstein DB, Steinberg D (1978) Lipoprotein and cholesterol metabolism in rabbit arterial endothelial cells in culture. Biochim Biophys Acta 529: 475-487

11. Vlodavsky I, Fielding PE, Fielding CJ, Gospodarowicz D (1978) Role of contact inhibition in the regulation of receptor-mediated uptake of low density lipoprotein in cultured vascular endothelial cells. Proc Natl Acad Sci USA 75: 356-360

12. Coetzee GA, Stein O, Stein Y (1979) Uptake and degradation of low density lipoproteins (LDL) by confluent, contact-inhibited bovine and human endothelial cells exposed to physiological concentrations of LDL. Atherosclerosis 33: 425-431

13. Schleicher E, Deufel T, Wieland OH (1981) Non-enzymatic glycosylation of human serum lipoproteins. FEBS Lett 129:1-4

14. Jaffe EA, Nachman RL, Becker CG, Minick CR (1973) Culture of human endothelial cells derived from umbilical veins. J Clin Invest $52: 2745-2756$

15. Weinstein DB, Carew TE, Steinberg D (1976) Uptake and degradation of low density lipoprotein by swine arterial smooth muscle cells with inhibition of cholesterol biosynthesis. Biochim Biophys Acta 424: 404-421
16. Habeeb AFSA (1966) Determination of free amino groups in proteins by trinitrobenzenesulfonic acid. Anal Biochem 14: 328-336

17. Weisgraber KH, Innerarity TL, Mahley RW (1978) Role of the lysine residues of plasma lipoproteins in high affinity binding to cell surface receptors on human fibroblasts. J Biol Chem 253: 9053-9062

18. Steinberg D (1978) Lipoprotein metabolism - new insights from cell biology. In: Kritchevsky D, Paoletti R, Holmes WL (eds) Drugs, lipid metabolism, and atherosclerosis. Plenum, New York, pp 443-467

19. Lowry OH, Rosebrough NJ, Farr AL, Randall RJ (1951) Protein measurement with the folin phenol reagent. J Biol Chem 193: $265-275$

20. Stevens VJ, Rouzer CA, Monnier VM, Cerami A (1978) Diabetic cataract formation: Potential role of glycosylation of lens crystallins. Proc Natl Acad Sci USA 75: 2918-2922

21. Cohen MP, Urdanivia E, Surma M, Ciborowski CJ (1981) Nonenzymatic glycosylation of basement membranes. Diabetes 30 : 367-371

22. Day JF, Ingebretsen CG, Ingebretsen WR Jr, Baynes JW, Thorpe SR (1980) Nonenzymatic glucosylation of serum proteins and hemoglobin: Response to changes in blood glucose levels in diabetic rats. Diabetes 29:524-527

23. Carew TE, Pittman RC, Marchand ER, Steinberg D (1983) Aortic endothelium is an active site of low density lipoprotein degradation in vivo in normal rabbits. Clin Res $31: 382 \mathrm{~A}$

24. Steinbrecher UP, Witztum JL (1983) Glycosylation of low density lipoproteins to an extent comparable to that seen in diabetes slows their catabolism. Diabetes (in press)

25. Brownlee M, Cerami A (1981) The biochemistry of the complications of diabetes mellitus. Ann Rev Biochem 50: 385-432

26. Witztum JL, Steinbrecher UP, Fisher M, Kesaniemi A (1983) Nonenzymatic glucosylation of homologous low density lipoprotein and albumin renders them immunogenic in the guinea pig. Proc Natl Acad Sci USA 80: 2757-2761

Received: 5 April 1983

and in revised form: 7 November 1983

Dr. Mara Lorenzi

Department of Medicine (H-811-C)

University Hospital

225 Dickinson Street

San Diego, CA 92103, USA 